\title{
PERLINDUNGAN HUKUM TERHADAP ADVOKAT ATAS INTERPRETASI OBSTRUCTION OF JUSTICE
}

\author{
Asrullah Dimas \\ Fakultas Hukum Universitas Hasanuddin, Makassar, Email : \\ asrullahdimass@gmail.com
}

Muh. Hasrul

Fakultas Hukum Universitas Hasanuddin, Makassar, Email : fhuhkumpultugas@gmail.com

\section{Hijrah Adhyanti Mirzana}

Fakultas Hukum Universitas Hasanuddin, Makassar, Email : adhyantihijrah@gmail.com

\begin{abstract}
Abstrak
Penelitian ini bertujuan menganalisis batasan delik obstruction of justice pada Undang-undang Nomor 21 Tahun 2001 Tentang Tindak Pidana Korupsi agar advokat dalam hal ini memiliki perlindungan hukum yang jelas dalam perkara tindak pidana korupsi. Penelitian ini menggunakan metode penelitian hukum normatif.Adapun hasil dari penelitian ini yaitu karakteristik Obstruction Of Justice, menyatakan 3 (tiga) unsur penting yaitu Tindakan tersebut menyebabkan tertundanya proses hukum (pending judicial proceedings);Pelaku mengetahui tindakannya atau menyadari perbuatannya (knowledge of pending proceedings); Pelaku melakukan atau mencoba tindakan menyimpang dengan tujuan untuk mengganggu atau mengintervensi proses atau administrasi hukum (acting corruptly with intent), Selanjutnya obstruction of justice merupakan delik materikl, sehingga delik tersebut mengindahkan adanya akibat yang ditimbulkan dari perbuatan, yakni perbuatan tercegah, terintangi atau tergagalkannya suatu penyidikan, penuntutan dan pemeriksaan sidang yang sedang dilaksanakan mengakibatkan lambatnya proses Peradilan sehingga tidak sesuai dengan prinsip peradilan yang sederhana , cepat dan biaya ringan. Selain dari hak imunitas advokat sebagai bentuk perlindungan hukum seharusnya delik obstruction of justice disematkan pada delik pidana materil bukan delik formil sehingga penekanan kasus tersebut adalah akibat dari perbuatan itu, seyogyanya untuk menilai perbuatan Officium Nobille maka peninjauannya pada akibat agar interpretasi dari kata mencegah,merintangi,dan menghalangi tidak sebatas perbuatan semata melainkan ada akibat yang ditimbulkan.
\end{abstract}

Kata Kunci: Perlindungan Hukum, Advokat, Obstruction of justice 


\section{Abstract}

This study aims to analyze the limits of the offense obstruction of justice in Law Number 21 of 2001 which is concerning about the Corruption so that advocates in this case have the clear legal protection in cases of criminal acts of the corruption. This study uses a normative legal research method. The results of this study are the characteristics of the Obstruction of Justice, which states 3 (three) important elements, namely that action causes pending judicial proceedings; the perpetrator knows his actions or is aware of his actions (knowledge of pending proceedings) ); The perpetrator commits or attempts deviant actions with the aim of disrupting or intervening in the legal process or administration (acting corruptly with intent). Furthermore, the obstruction of justice is a material offense, so that the offense ignores any consequences arising from the act, namely actions are prevented, obstructed or failed to occur. ongoing investigations, prosecutions and trial hearings have resulted in the slow process of the judiciary so that it is not in accordance with the principles of a simple, fast and low cost trial. Apart from the right of an advocate's immunity as a form of legal protection, the obstruction of justice offense should be attached to a material criminal offense not a formal offense so that the emphasis of the case is the result of that act. and hindering is not just an act, but there are the consequences itself.

Keyword: legal protection, advocate, Obstruction of justice

\section{PENDAHULUAN}

Penegakan hukum mencakup segala aktivitas yang dimaksudkan agar hukum sebagai perangkat kaidah normatif yang mengatur dan mengikat para subjek hukum dalam segala aspek kehidupan bermasyarakat dan bernegara benar-benar ditaati dan dijalankan sebagaimana mestinya. Dalam arti sempit, penegakan hukum menyangkut kegiatan penindakan terhadap setiap pelanggaran terhadap peraturan perundang-undangan, khususnya melalui proses peradilan pidana yang melibatkan peran aparat kepolisian, kejaksaan, Advokat atau pengacara dan badan-badan peradilan lainnya.

Setelah Undang-Undang Nomor 18 Tahun 2003 tentang Advokat(Undang-undang Advokat) berlaku, di antara keempat sub sistem peradilan pidana tersebut terdapat unsur Advokat (dengan berbagai istilahnya) yang mempunyai peranan sangat penting dalam sistem peradilan pidana di Indonesia.

Dalam konteks sistem hukum, terkait penanganan kasus pidana Advokat menjalankan tugas profesinya di Indonesia dengan mendasarkan 
pada sistem hukum dan metode pendekatan hukum Civil Law yang menempatkan hukum tertulis sebagai sumber hukum utama dalam praktik penerapan hukum.

Sementara pada sistem hukum negara-negara bagian Amerika Serikat sepenuhnya dibangun di atas tradisi hukum Common Law yang saling berhubungan. Adanya perbedaan-perbedaan hukum diantara negaranegara bagian bisa dimanfaatkan Advokat di Amerika Serikat untuk mencari pengadilan-pengadilan yang dapat menerima kasus-kasus yang ditangani atau memilih negara-negara bagian yang legislasinya lebih menguntungkan kliennya. Selain itu ada beberapa cara penyeragaman hukum dalam sistem hukum Amerika. Baik dalam perkara perdata maupun pidana, Advokat di Indonesia memiliki peran yang signifikan dalam melakukan pendampingan bagi yang membutuhkan, khususnya klien yang tengah berperkara.

Ada beberapa hubungan advokat dan klien yang perlu mendapat perhatian yaitu (Bagir Manan : 2009);

1. Hubungan antara advokat dank lien adalah hubungan kepercayaan (trust) bukan pertama-tama hubungan bisnis. Tidak pantas advokat memperkarakan klien yang tidak membayar honorarium yang dijanjikan.

2. Sekal advokat menandatangani surat kuasa, harus berusaha sungguh-sungguh mengurus dan membela kepentingan hukum klien sampai tahap demi tahap perkara diselesaikan. Tidak boleh terjadi, advokat mentelantarkan kepentingan hukum klien.

3. Advokat harus mendorong klien bertindak jujur dan benar dan harus mencegah apalagi membantu upaya klien menempuh caracara yang bertentangan dengan hukum untuk memenangkan perkara. Perkataan-perkataan seperti itu "terserah saudara" apalagi menjadi "perantara" antara klien dan penegak hukum lainnya sekali-kali tidak boleh dilakukan karena bertentangan dengan etik dan hukum.

Advokat berusaha memperjuangkan keadilan bagi kliennya dengan mengemukakan fakta yang dimilikinya dan menyesuaikannya dengan ketentuan-ketentuan dalam peraturan perundang-undangan atau hukum positif. Dalam sistem peradilan pidana di Indonesia, Advokat sangat berperan penting dalam konsepsi keadilan. Hal tersebut dapat dilihat dengan pengaturannya dalam Bab VI tentang Tersangka dan Terdakwa pada Undang-Undang Nomor 8 Tahun 1981 tentang Kitab Undang-Undang Hukum Acara Pidana (KUHAP) pada intinya membahas terkait tugas dan fungsi advokat dalam melakukan pendampingan tersangka/terdakwa dalam pengadilan. 
Berdasar pada penjelasan Pasal 16 Undang-undang Advokat yang dimaksud dengan iktikad baik adalah menjalankan tugas profesi demi tegaknya keadilan berdasarkan hukum, sementara frasa sidang pengadilan diartikan sebagai sidang dalam setiap tingkat pengadilan di semua lingkungan peradilan. Kemudianrumusan tersebut diperluas ruang lingkupnya melalui putusan MK Nomor 26/PUU-XI/2013 menjadi:

"Advokat tidak dapat dituntut baik secara perdata maupun pidana dalam menjalankan tugas profesinya dengan iktikad baik untuk kepentingan pembelaan klien di dalam maupun di luar sidang pengadilan".

Ketentuan tersebut berarti bahwa, Advokat saat melaksanakan profesi tidak dapat dituntut, baik perdata maupun pidana, bukan hanya di dalam, tetapi juga di luar persidangan. Kemudian secara khusus berbicara mengenai proses untuk kasus pidana, dimulai dari penyelidikan, penyidikan, penuntutan, maupun di tingkat persidangan pengadilan, kerap kali terjadi perbuatan-perbuatan yang bertujuan untuk menghalang-halangi dan merintangi proses peradilan pidana, dikenal dengan istilah obstruction of justice.

Tindakan obstruction of justice juga sering kali dikaitkan dengan profesi Advokat dalam melakukan pembelaan terhadap kliennya namun dalam konteks yang positif. Istilah obstruction of justice merupakan terminologi hukum yang berasal dari literatur Anglo Saxon, yang dalam ilmu hukum pidana di Indonesia sering diterjemahkan sebagai "tindak pidana menghalangi proses hukum". Menurut kamus Black's Law Dictionary, obstruction of justice memiliki pengertian yaitu :

"The noncompliance with the legal system by interfering with (1) the law administration or procedures, (2) not fully disclosing information or falsifying statements, and (3) inflicting damage on an officer, juror or witness."

Regulasi Kitab Undang-Undang Hukum Pidana (KUHP) tentang obstruction of justice merupakan tujuan hal ini berbeda dengan pengaturan dalam Pasal 21 Undang-Undang Nomor 31 Tahun 1999 Jo. UndangUndang Nomor 20 tahun 2001 tentang Pemberantasan Tindak Pidana Korupsi yang berbunyi:

"Setiap orang yang dengan sengaja mencegah, merintangi, atau menggagalkansecara langsung atau tidak langsung penyidikan, penuntutan, dan pemeriksaan disidangpengadilan terhadap tersangka atau terdakwa ataupun para saksi dalam perkara korupsi,dipidana dengan pidana penjara paling singkat 3 (tiga) tahun dan paling lama 12 (duabelas) tahun dan atau denda paling sedikit Rp. 150.000.000,00 (seratus lima puluh jutarupiah) dan paling banyak Rp. 600.000.000,00 (enam ratus juta rupiah)." 
Pada Pasal tersebut tindak pidana berupa mencegah, merintangi, atau menggagalkan secara langsung atau tidak langsung penyidikan, penuntutan, dan pemeriksaan di sidang pengadilan terhadap tersangka dan terdakwa ataupun para saksi dalam perkara korupsi dianggap merupakan sifat dari suatu perbuatan, namun yang menjanggal adalah frasa "tidak langsung" dalam Pasal 21 Undang-Undang 31 Tahun 1999 Jo. UndangUndang Nomor 20 Tahun 2011 Tentang pemberantasan tindak pidana korupsi sangat absurd dan menimbulkan multitafsir bagi penyidik bahkan para hakim yang menangani kasus seperti ini, maka dari itu patutlah kiranya Frasa tersebut lebih diperjelas dengan menimbang Asas Legalitas Hukum Pidana dimana semua aturan harus jelas dan berdasarkan kepastian hukum itu sendiri.

Lebih jelas Pasal 21 Undang-Undang Nomor 31 Tahun 1999 Jo. Undang-Undang Nomor 20 tahun 2001 tentang Pemberantasan Tindak Pidana Korupsi tindak pidana obstruction of justice diatur sebagai perbuatan. Dengan adanya pergeseran pengertian, dalam praktik, antara hak imunitas advokat dan tindak pidana obstruction of justice ini kerap bersinggungan. Advokat tak jarang diduga melanggar hukum ketika membela kliennya hanya karena memegang teguh kode etik advokat terutama ketika menjaga rahasia kliennya. Hal bersinggungan ini kemudian menjadi masalah. Hal yang dipercayakan klien, dia (advokat) wajib tidak beritahukan kepada siapapun. Hal yang bersifat rahasia (klien) tidak harus diberitahukan karena memang bukan tugas advokat. Hal yang bersinggungan inilah kemudian yang memunculkan sebuah permasalahan berkaitan dengan perspektif menghalang-halangi proses peradilan (obstruction of justice) versus hak imunitas seorang advokat yang diatur di dalam Pasal 16 Undang-Undang Nomor 18 tahun 2003 tentang advokat.

Berdasarkan uraian di atas, penulis berharap dapat melakukan penelitian terkait batasan Delik Obstruction of Justice serta bentuk perlindungan hukum advokat atas interpretasi selama ini yang dilakukan oleh para penegak hukum" lebih lanjut dengan judul Perlindungan Hukum terhadap Advokat atas Interpretasi Obstruction Of Justice pada perkara Tindak Pidana Korupsi.

\section{METODE PENELITIAN}

Metode penelitian yang digunakan merupakan metode penelitian hukum normatif. Data dalam penelitian ini terdapat dua jenis data, yaitu berupa data primer dan data sekunder. Data primer merupakan bahan hukum yang bersifat autoritatif artinya mempunyai otoritas yang terdiri dari perundang-undangan, catatan-catatan resmi atau risalah dalam pembuatan undang-undang dan putusan-putusan hakim. 
Sedangkan data sekunder, berupa semua publikasi tentang hukum yang bukan merupakan dokumen-dokumen resmi. Publikasi tentang hukum meliputi buku-buku teks, kamus-kamus hukum, jurnal-jurnal hukum dan komentar-komentar atas putusan pengadilan. Kemudian juga menggunakan sumber-sumber bahan-bahan non hukum. Bahan-bahan non hukum berupa buku-buku sepanjang mempunyai relevansi dengan topik penelitian.

\section{PEMBAHASAN}

\section{Batasan Delik Obstruction Of Justice dalam Perkara Tindak Pidana Korupsi}

Perumusan Undang-undang Nomor 20 Tahun 2001 didasarkan pada fakta bahwa korupsi sangat merugikan keuangan atau perekonomian Negara dan menghambat pembangunan nasional. ${ }^{1}$ Penggantian tersebut diharapkan mampu memenuhi dan mengantisipasi perkembangan kebutuhan hukum masyarakat dalam rangka mencegah dan memberantas secara lebih efektif setiap bentuk tindak pidana yang sangat merugikan keuangan ataupun perekonomian Negara. Pembentukan undang-undang tersebut dilakukan berdasarkan dari aspirasi masyarakat untuk memberantas korupsi dan bentuk penyimpangan lainnya yang modus operandinya semakin meningkat yang karena dalam kenyataannya, kasus korupsi telah menimbulkan kerugian Negara yang sangat besar yang pada gilirannya berdampak pada timbulnya krisis diberbagai bidang. Oleh karena itu upaya pencegahan dan pemberantasan korupsi di Indonesia perlu semakin ditingkatkan dan diintensifkan dengan tetap memjunjung tinggi hak asasi manusia dan kepentingan masyarakat.

Ketentuan tindak pidana Obstruction Of Justice yang pada mulanya diatur dalam pasal 18 Undang-undang Pemberantasan Tindak Pidana Korupsi. Kemudian dikritisi oleh beberapa fraksi yang hadir dalam penyusunan Undang-Undang Nomor 31 Tahun 1999. Sebelum diatur dalam pasal 21 Undang-undang Nomor 31 Tahun 1999, tindak pidana Obstruction Of Justice telah terlebih dahulu diatur dalam Pasal 221 Kitab Undangundang Hukum Pidana.

Pengaturan mengenai tindak pidana Obstruction Of Justice bukan merupakan hal baru lagi. Alasan dari pengaturan tindak pidana Obstruction Of Justice didalam Kitab Undang-Undang Hukum pidana adalah tidak pidana Obstruction Of Justice merupakan bagian dari tindak pidana contempt of court yang berarti bahwa sikap merendahkan pengadilan. karena penghinaan merupakan kesengajaan menyerang kehormatan atau

${ }^{1}$ Konsiderans Menimbang butir a Undang-Undang Nomor 31 Tahun 1999 tentang Pemberantasan Tindak Pidana Korupsi 
nama baik orang lain, sedangkan sikap merendahkan yang ditujukan oleh seseorang terhadap orang lain yang tidak selalu harus dipandang sebagai suatu penghinaan. ${ }^{2}$ Para pembentuk Kitab Undang-Undang Hukum pidana juga memandang bahwa perbuatan Obstruction Of Justice sebagai tindak pidana yang ditujukan terdahap pengadilan.

Oleh karena alasan itulah dibentuklah pembaharuan mengenai ketentuan pasal yang mengatur tindak pidana Obstruction Of Justice. Tindak pidana Obstruction Of Justice pada mulanya diatur dalam pasal 18, Pasal 19, Pasal 20 dan Pasal 21 Undang-Undang Pemberantasan Tindak Pidana Korupsi, ${ }^{3}$ namun setelah adanya pembahasan, pasal-pasal tersebut menjelma menjadi pasal 20, 21, 22, dan 23.

Salah satu hal yang perlu diperhatikan dengan pengaturan Obstruction Of Justice dalam KUHP adalah bahwa dari sekian banyak pasal yang dapat dianalogikan sebagai tindakan Obstruction Of Justice, hanya ada satu pasal yang secara jelas menyebutkan unsur tujuan "untuk menghalanghalangi atau menyusahkan pemeriksaan dan penyelidikan atau penuntutan" sebagaimana terdapat dalam pasal 221 ayat (1) dan (2). Terdapat beberapa pasal yang paling relevan sebagai tindakan Obstruction Of Justice, diantaranya adalah : ${ }^{4}$

2 Lamintang dan Theo Lamintang, Delik-Delik Khusus Kejahatan Terhadap Kepentingan Hukum Negara, Grafika ,Jakarta Sinar, 2010, Hal. 606.

${ }^{3}$ Risalah Undang-Undang Nomor 31 Tahun 1999 tentang Pemberantasan Tindak Pidana Korupsi Buku 1, Penyampaian Rancangan Undang-Undang Pemberantasan Tindak Pidana Korupsi, Tanggal 8 Februari 1999

${ }^{4}$ Shinta Agustina dan Saldri Isra. Et.al, Obstruction Of Justice, Themis Book, Jakarta, 2015,Hal. 33-37. 
Tabel 1. Penjelasan Pasal Delik Obstruction of Justice

\begin{tabular}{|c|c|c|}
\hline & Pasal 221 KUHP & $\begin{array}{c}\text { Pasal } 21 \text { Undang-undang Nomor } \\
20 \text { Tahun } 2001 \text { Tentang Tindak } \\
\text { Pidana Korupsi }\end{array}$ \\
\hline Frasa Pasal & $\begin{array}{l}\text { 1) Barang siapa dengan sengaja } \\
\text { menyembunyikan orang yang } \\
\text { melakukan kejahatan atau dituntut } \\
\text { karena melakukan kejahatan, atau } \\
\text { barang siapa memberi pertolongan } \\
\text { kepadanya untuk menghindari } \\
\text { penyidikan atau penahanan oleh } \\
\text { pejabat kehakiman atau kepolisian } \\
\text { atau oleh orang lain yang menurut } \\
\text { ketentuan undang-undang terus } \\
\text { menerus atau untuk sementara } \\
\text { waktu diserahi menjalankan } \\
\text { jabatan kepolisian." } \\
\text { 2) Barang siapa setelah dilakukan } \\
\text { suatu kejahan dan dengan maksud } \\
\text { untuk menutupinya atau untuk } \\
\text { menghalanghalangi atau } \\
\text { mempersukar penyidikan } \\
\text { ataupenuntutannya,menghancurka } \\
\text { n,menghilangkan,menyembunyika } \\
\text { n benda-benda terhadap mana atau } \\
\text { dengan mana kejahatan dilakukan } \\
\text { atau bekas-bekas kejahatan } \\
\text { lainnya, atau menariknya dari } \\
\text { pemeriksaan yang dilakukan oleh } \\
\text { pejabat kehakiman atau kepolisian } \\
\text { maupun oleh orang lain, yang } \\
\text { menurut ketentuan undang- } \\
\text { undang terus-menerus atau untuk } \\
\text { sementara waktu diserahi } \\
\text { menjalankan jabatan kepolisian. }\end{array}$ & $\begin{array}{l}\text { "Setiap orang yang dengan sengaja } \\
\text { mencegah, merintangi, atau } \\
\text { menggagalkan secara langsung atau } \\
\text { tidak langsung penyidikan, } \\
\text { penuntutan, dan pemeriksaan di } \\
\text { sidang pengadilan terhadap tersangka } \\
\text { dan terdakwa ataupun para saksi } \\
\text { dalam perkara korupsi, dipidana } \\
\text { dengan pidana penjara paling singkat } \\
3 \text { (tiga) tahun dan paling lama } 12 \text { (dua } \\
\text { belas) tahun dan atau denda paling } \\
\text { sedikit Rp. 150.000.000,00 (seratus } \\
\text { lima puluh juta rupiah) dan paling } \\
\text { banyak Rp } 600.000 .000,00 \text { (enam } \\
\text { ratus juta rupiah)." }\end{array}$ \\
\hline Perbedaan & $\begin{array}{l}\text { Ancaman Penjara dan Denda sangat } \\
\text { kurang dalam sehingga tidak } \\
\text { mencapai level efek jerah bagi } \\
\text { pelanggar Delik Obstruction of } \\
\text { justice pada KUHP }\end{array}$ & $\begin{array}{l}\text { Ancaman Penjara dan Denda sangat } \\
\text { tepat dan mengikuti perkembangan } \\
\text { zaman, sehingga efek jerah bisa } \\
\text { langsung dirasakan oleh si pelaku. }\end{array}$ \\
\hline
\end{tabular}


Sumber : Dokumen Negara (Undang-undang No.20 Tahun 2001 Tentang Tindak Pidana Korupsi dan KUHP)

Para pembentuk kitab Undang-undang hukum pidana juga memandang bahwa perbuatan Obstruction Of Justice sebagai perbuatan yang membahayakan jaminan yang diberikan oleh Negara untuk melihara kebenaran, keadilan dan kepercayaan umum. ${ }^{5}$ Tindak pidana Obstruction Of Justice, selain diatur dalam KUHP juga diatur dalam Undang-Undang Nomor 20 Tahun 2001 Tentang Pemberantasan Tindak Pidana Korupsi. Alasan pengaturan tindak pidana Obstruction Of Justice dalam Undangundang Nomor 20 Tahun 2001 Tentang Pemberantasan Tindak Pidana Korupsi adalah karena perbuatan menghalang-halangi, mempersulit, yang mempunyai maknanya menguntungkan bagi tindak pidana korupsi, maka harus diancam dengan pidana yang cukup berat. Pasal-pasal Obstruction Of Justice dirancang untuk melindungi individu-individu yang terlibat dalam proses hukum dan mencegah "gugurnya" proses penegakan keadilan melalui tindakan-tindakan menyimpang. ${ }^{6}$

Menurut Ganjar Bondan Laksana, pasal Obstruction Of Justice difungsikan secara luas terhadap segala tindakan yang berkeinginan mengganggu proses penegakan hukum dalam segala lini maupun dalam berbagai bentuk. ${ }^{7}$ Selain itu alasan lain yang dipaparkan oleh Muhammadd Buay mengemukakan bahwa korupsi jelas merugikan keuangan Negara yang berarti merugikan seluruh rakyat, membahayakan pembangunan, bertentangan dengan hukum, bertentangan dengan moral dan rasa keadilan dan lebih dari itu semua, jelas korupsi bertentangan dengan hukum-hukum agama. ${ }^{8}$

Penulis beranggapan bahwa Ketentuan dalam Pasal 221 Kitab Undang-Undang Hukum Pidana (KUHP) dianggap tidak mampu menjangkau berbagai bentuk perilaku berkategori sebagai perbuatan mengahalangi proses peradilan tindak pidana korupsi. Ancaman pidana Pasal 221 KUHP, dianggap terlalu ringan, dibandingkan dengan akibat yang ditimbulkan oleh perilaku menghalangi proses peradilan terhadap tindak pidana korupsi, disatu sisi Pasal 21 Undang-undang Nomor 20 Tahun 2001 Tentang Pemberantasan Tindak Pidana Korupsi masih memiliki perdebatan antara delik formil atau materil dikarenakan Pasal tersebut tidak mengatur

${ }^{5}$ Lamintang dan Theo Lamintang, Delik-Delik Khusus Kejahatan Membahayakan Kepercayan Umum tethadap Surat Alat Pembayaran Alat Bukti dan Peradilan, Sinar Grafika, Jakarta, 2009, Hal. 295.

${ }^{6}$ Shinta Agustina et.al, Op.Cit, Hal. 83.

${ }^{7}$ Shinta Agustina et.al, Op.cit. Hal. 86.

8 Risalah Undang-Undang Nomor 3 Tahun 1971, Rapat pleno terbuka ke 6, Pembicaraan Tingkat III (Pemandangan Umum Para Anggota) mengenai RUU Tentang Pemberantasan Tindak Pidana Korupsi P.2/1970-1971, Hari Jumat, 4 September 1970 
akibat, sedangkan jika ditinjau dari unsur perbuatan maka delik ini termasuk materil karena memeiliki akibat dari perbuatan tersebut.

Selanjutnya, penjelasan mengenai tindak pidana Obstruction Of Justice ternyata telah dikemukakan oleh Eddy Os Hiariej Guru Besar Hukum Pidana Fakultas Hukum UGM. Penafsiran doktriner terhadap tindak pidana menghalanh-halangi proses hukum adalah suatu perbuatan, baik melakukan atau tidak melakukan sesuatu dengan maksud menunda, mengganggu, atau mengintervensi proses hukum dalam suatu kasus. Per definisi, tindak pidana menghalangi proses hukum yang demikian mengandung makna bahwa tindakan yang dilakukan sejak awal tersebut punya motif untuk menghalangi proses hukum. ${ }^{9}$ Selain itu batasan dan kriteria dari tindak pidana ini menurut undang-undang pemberantasan tindak pidana korupsi ini adalah perbuatan yang termasuk dalam Obstruction Of Justice dapat berupa perbuatan apapun, dari yang paling ringan (mempengaruhi hakim/juri dengan tulisan atau komentar). Dan yang paling berat (menggunakan kekerasan yang mengakibatkan kematian pada saksi). Tindakan menghalangi proses hukum, tidaklah mengharuskan bahwa perbuatan itu memang telah mengakibatkan suatu proses hukum terhalangi/terhambat oleh perbautan pelaku, melainkan hanya diisyaratkan adanya maksud atau niat dari pelaku untuk meghalangi proses hukum. ${ }^{10}$

Ukuran dari maksud atau niat untuk menghalangi proses hukum menunjukkan bahwa tindak pidana ini diklasifikasikan sengaja (dolus delict). Mengikuti doktrin tentang sengaja, maka maksud atau niat sebagai unsur tindak pidana, tidaklah harus merupakan tujuan, tapi juga dapat berupa kesadaran/keinsyafan bahwa terhalanginya atau terhambatnya proses hukum pasti atau mungkin akan terjadi karena perbuatannya. Pelaku tidak harus meghendaki suatu proses hukum itu akan tercegah atau terintangi atau tergagalkan oleh perbutaannya apalagi bahwa proses tersebut memang telah tercegah, terintangi atau tergagalkan, melainkan cukup apabila dia mengetahui bahwa perbuatannya dapat mencegah, merintangi aau menggagalkan suatu proses hukum. ${ }^{11}$ Berdasarkan praktiknya, mengukur adanya niat dan maksud harus seseuai dengan fakta dari persidangan yang meliputi fakta sebelum perbuatan pidana dilakukan, fakta saat perbuatan pidana dilakukan dan fakta telah terselesainya perbuatan pidana.

\footnotetext{
${ }^{9}$ Eddy Os Hiariej, Guru Besar Hukum Pidana Fakultas Hukum UGM, Obstruction Of Justice dan Hak Angket DPR, lihat pula pada, https://www.pressreader.com/indonesia/kompas/20170721/281612420458169, pada hari 22 Maret 2021 pukul 19.22 WITA

${ }^{10}$ Shinta Agustina et.al, op.Cit, Hal. 31.

${ }^{11}$ Shinta Agustina et.al, op.Cit, Hal .114.
} 
Sedangkan Menurut Shinta Rumusan mengenai tindak pidana Obstruction Of Justice dalam Undang-Undang Pemberantasan Tindak Pidana Korupsi tersebut termasuk kedalam jenis dari delik Formil. Hal tersebut dapat diketahui Berdasarkan paparan rumusan pasal 21 tersebut, maka dapat ditarik kesimpulan:
a. Setiap orang
b. Dengan sengaja
c. Mencegah, merintangi atau menggagalkan secara langsung atau tidak langsung
d. Penyidikan, penuntutan dan pemeriksaan di siding pengadilan terhadap tersangja, terdakwa ataupun para saksi dalam perkara korupsi.

Berdasarkan unsur-unsur pasal 21 tersebut maka terlihat bahwa tindak pidana dalam rumusan pasal tersebut termasuk dalam jenis delik formil. Hal ini dikarenakan rumusan pasal tersebut tidak mengatur tentang akibat yang harus terjadi. Unsur mencegah, merintangi, ataupun menggagalkan secara langsung atau tidak langsung, dalam rumusan tindak pidana tersebut mengacu kepada perbuatan yang dapat berupa atau berbentuk perbuatan apapun yang bersifat mencegah, merintangi atau mengagalkan. ${ }^{12}$

Unsur perbuatan dalam ketentuan tersebut adalah dengan sengaja mencegah, merintangi, atau menggagalkan secara langsung atau tidak langsung, apabila dilihat berdasarkan karakteristik perbuatan Obstruction Of Justice, sebagaimana dijelaskan oleh Kendall, yang menyatakan perbuatan atau percobaan tersebut dinyatakan sebagai tindak pidana menghalangi proses hukum, apabila terpenuhi 3 (tiga) unsur penting yaitu

a. Tindakan tersebut menyebabkan tertundanya proses hukum (pending judicial proceedings);

b. Pelaku mengetahui tindakannya atau menyadari perbuatannya (knowledge of pending proceedings);

c. Pelaku melakukan atau mencoba tindakan menyimpang dengan tujuan untuk mengganggu atau mengintervensi proses atau administrasi hukum (acting corruptly with intent),

Perbuatan dalam perumusannya sebagai suatu perbuatan/ tindak pidana (strafbaar feit), menurut Simons haruslah memuat beberapa unsur yakni: ${ }^{13}$

\footnotetext{
${ }^{12}$ Sinta Agustina, et.al, Op.Cit, Hal. 85.

${ }^{13}$ Kartanegara Op Cit. Hal. 65.
} 

Adhyanti Mirzana)

a. Suatu perbuatan manusia (menselijk handelingen). Dengan handeling dimaksudkan tidak saja "een doen" (perbuatan), akan tetapi juga "een nalaten" (mengakibatkan);

b. Perbuatan itu (yaitu perbuatan dan mengakibatkan) dilarang dan diancam dengan hukuman oleh undang-undang;

c. Perbuatan itu harus dilakukan oleh seseorang yang dapat dipertanggung jawabkan, artinya dapat dipersalahkan karena melakukan perbuatan tersebut.

Berdasarkan penjelasan tersebut, suatu perbuatan mencegah, merintangi dan menggagalkan haruslah memuat unsur-unsur perbuatan yang ada dalam suatu tindak pidana sebagaimana dalam rumusan Simons mengenai strafbaar feit. Bahwa perbuatan mencegah, merintangi dan menggagalkan yang dimaksudkan sebagai perbuatan manusia (menselijk handelingen) dalam ketentuan Pasal 21 Undang-Undang No. 31 Tahun 1999 Tentang Pemberantasan Tindak Pidana Korupsi, secara nyata telah dilarang dan diancam dengan pidana. Terhadap perbuatan atau tindakan manusia tersebut dilihat dari adanya akibat aktif, tindakan tersebut dapat merupakan: ${ }^{14}$

a. Een bewuste handeling ( tindakan dengan kesadaran );

b. Een gewilde handeling (tindakan disertai dengan kemauan).

Sehingga apabila perbuatan dilakukan dilakukan secara tidak sadar maka bukan merupakan tindak pidana dan tidak dapat dikenai pertanggung jawaban pidana. Dalam perbuatan mencegah, merintangi dan menggagalkan secara langsung dan tidak langsung dalam ketentuan Pasal 21 UndangUndang Nomor 20 Tahun 2001 Tentang Pemberantasan Tindak Pidana Korupsi, tentunya perbuatan tersebut haruslah dilakukan setelah adanya suatu perintah tertentu dalam pelaksanaan penyidikan, penuntutan dan pemeriksaan sidang, sebagai unsur keadaan yang ada dalam ketentuan tersebut, sehingga seseorang yang melakukan perbuatan tersebut haruslah mengetahui bahwa perbuatan mencegah, merintangi dan menggagalkan secara langsung dan tidak langsung adalah ada hubungannya dengan proses penyidikan, penuntutan dan pemeriksaan sidang yang sedang dilaksanakan atau memiliki motif untuk melakukan perbuatan tersebut.

Berdasarkan uraian diatas maka penulis menarik sebuah konklusi bahwa perbuatan mencegah, merintangi dan menggagalkan secara langsung dan tidak langsung dalam ketentuan Pasal 21 Undang-Undang Nomor 20 Tahun 2001 Tentang Pemberantasan Tindak Pidana Korupsi, merupakan delik materil, sehingga delik tersebut mengindahkan adanya akibat yang ditimbulkan dari perbuatan tersebut, yakni perbuatan tercegah, terintangi 
atau tergagalkannya suatu penyidikan, penuntutan dan pemeriksaan sidang yang sedang dilaksanakan mengakibatkan lambatnya proses Peradilan sehingga tidak sesuai dengan prinsip peradilan yang sederhana, cepat dan biaya ringan, jadi dalam penerapan delik tersebut bukan berarti dalam pasal tersebut tidak mengatur akibat namun dalam implementasi pasal tesebut sangat syarat akan akibat. Oleh karena itu, dalam pemberantasan tindak pidana korupsi haruslah dihindarkan dari segala bentuk perbuatan yang dapat mengalang-halangi proses peradilan dalam pemberantasan tindak pidana korupsi tersebut sehingga diperlukan pengaturan khusus mengenai perbuatan menghalang-halangi penyidikan atau yang disebut dengan Obstruction Of Justice agar pemberantasan tindak pidana korupsi dapat berjalan secara efektif sehingga sehingga tujuan dari pembangunan sosial dapat berjalan dengan maksimal.

Tabel 2. Penjelasan Putusan Kasus Obstruction Of Justice

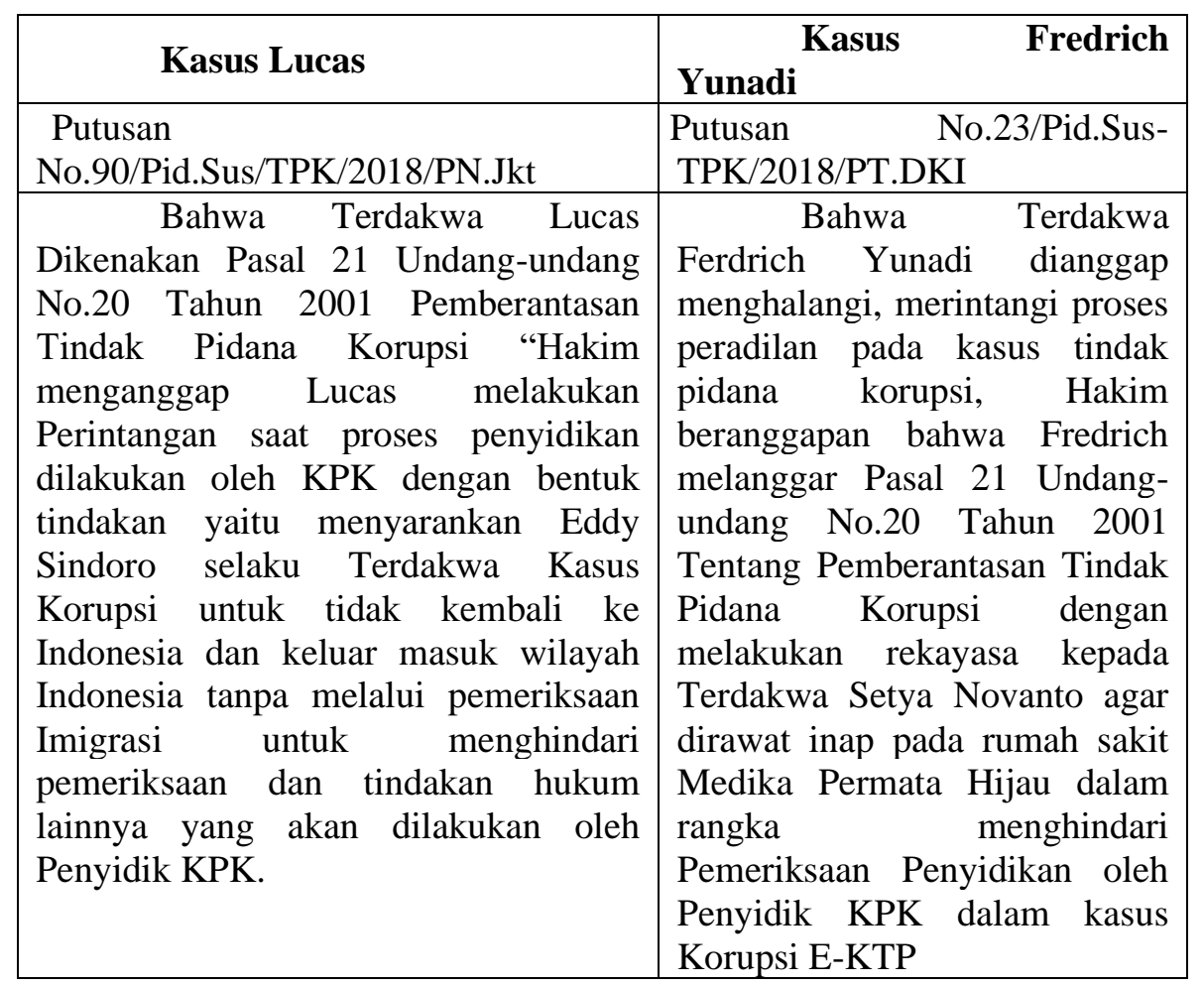

Sumber : Direktori Putusan MA (Putusan No.90/Pid.Sus/TPK/2018/PN.Jkt dan Putusan No.23/Pid.Sus-TPK/2018/PT.DKI)

Berdasarkan putusan diatas penulis berangapan bahwa penekanan unsur perbuatan sudah seyogyanya diterapkan dalam sistem peradilan khusus TIndak Pidana Korupsi terkait delik obstruction of justice. Dudukan kedua kasus tersebut sama-sama menunda proses penyidikan yang akan 
dilakukan oleh KPK dengan merintangi proses peradilan, semisal kasus Lucas yang secara sadar menyarankan terdakwa Eddy agar tidak kembali ke Indonesia agar menghindari Penyidik KPK sama halnya dengan Fredrich yang merekayasa secara aktif proses rawat inap terdakwa Setya Novanto. Maka kedua kasus tersebut mengakibatkan proses penyidikan menjadi terhambat atau tertundanya proses hukum (pending judicial proceedings).

\section{Faktor Penegak Hukum Memengaruhi Penegakan Hukum Pasal 27 Ayat (3) UU ITE}

Advokat sebagai officer of the court yakni sebagai pejabat pada proses peradilan sehingga memiliki otoritas untuk selalu menjagi aspek officium nobille profesinya, sehingga ketentuan pasal 14 Undang-undang Advokat yang mengatur kebebasan advokat dalam berprofesi mengandung makna tidak terdapatnya intervensi baik dalam bentuk intimidasi , rintangan serta tindakan dari aparat penegak hukum lain untuk merendahkan profesi advokat. Adapula klausa sidang pengadilan yang menjadi lingkup dari hidupnya hak imunitas advokat dapat dilihat pada penjelasan Pasal 16 Undang-undang Advokat yang dalam penjelasannya belum cukup untuk membuat jelas sehingga menjadi lex certa. Terhadap hal tersebut telah dijelaskan kembali pada Putusan MK No 26/PUU-XI/2013 berkaitan dengan pengujian Pasal 16 tersebut. ${ }^{15}$

Diaturnya Obstruction Of Justice karena pada pokoknya tindakan tersebut berpotensi merintangi serta menghambat proses hukum pemberantasan korupsi. ${ }^{16}$ Kompleksitas tindak pidana korupsi yang semakin tinggi telah jelas berdampak pada kerugian dalam aspek keuangan dan perekonomian negara menjadikan segala tindakan lain yang dianggap menghalangi proses penegakannya adalah suatu tindak pidana. ${ }^{17}$ Berdasarkan hal tersebut maka hak imunitas yang ada dalam tubuh advokat memiliki batasan batasan yang berlandas pada itikad baik dalam proses memberikan jasa hukum pada klien. Hak imunitas merujuk pada penjelasan Pasal 16 Undang-undang Advokat menyuratkan dapat ditariknya dua syarat utama yang harus berlandas pada itikad baik dan dilindungi oleh hak imunitas adalah terkait dengan tindakan advokat dalam pelaksanaan tugas

15 Kresnadinata, Putu, and I. Putu Rasmadi Arsha Putra. "Batasan Perlindungan Advokat Saat Memberi Jasa Hukum Di Luar Pengadilan Ditinjau Dari Putusan Mk No. 26/PuuXi/2013." Kertha Wicara: Journal Ilmu Hukum 8. No. 5 :1-14.

16 Yoga, I. Nyoman Darma, I. Gusti Agung Ayu Dike Widhiyaastuti, and AA Ngurah Oka Yudistira Darmadi. "Kewenangan Komisi Pemberantasan Korupsi Menangani Obstruction Of Justice Dalam Perkara Korupsi." Kertha Wicara: Journal Ilmu Hukum: 114.

${ }^{17}$ Ibid. 
dan fungsi profesinya sehingga secara sederhana diartikan sebagai suatu tindakan yang tidak melanggar hukum. ${ }^{18}$ Hak imunitas ini hanya berlaku pada saat advokat menjalankan profesinya dengan tetap menegakkan hukum dan undang undang serta kode etik advokat. ${ }^{19}$

Hal ini menyebabkan ketika suatu undang undang lain diluar dari Undang-undang Advokat mengatur penegakan hukum bagi setiap orang tidak terkecuali advokat yang memiliki hak imunitas jika dianggap melakukan perbuatan yang unsurnya yakni "mencegah, merintangi atau menggagalkan" yang dilakukan dengan cara langsung maupun tidak langsung dalam proses hukum yang bermuara di pengadilan maka dapat diancam oleh Pasal 21 Undang-undang Tindak Pidana Korupsi tersebut. Adanya hak imunitas tidak menjadikan profesi advokat sebagai profesi yang kebal hukum, karena pembatasan hak imunitas ada pada itikad baik yang dijalankan selama memberikan pendampingan hukum kepada klien, ketiadaan itikad baik pada advokat menjadikan hak imunitas gugur secara langsung. Hal ini sejalan dengan adagium equalitiy before the law yang dijamin secara konstitutif.

Suatu perkara ataupun juga pejabat pengadilan serta penegak hokum yang terlibat dalam proses hokum tersebut, hal inilah yang digolongkan pada obstructing justice. ${ }^{20}$ Agar mampu dimintai pertanggungjawaban pidana kepada advokat maka harus mempertimbangkan hak imunitas yang menjadi kekebalan dari advokat dalam menjalankan profesinya. Hak imunitas dipandang hidup ketika advokat menjalankan profesinya yang berpegang teguh pada Undang-undang Advokat dan kode etik profesi serta adanya itikad baik yakni sesuai dengan ius constitutum serta tidak melawan hukum dengan demikian secara a contrario itikad baik diluar maupun didalam persidangan harus dijunjung tinggi oleh advokat. Pada tindakan Obstruction Of Justice yang diklasifikasi sebagai salah satu dari contempt of court, aspek pertanggungjawaban pidana pada profesi advokat memandang advokat dalam melakukan pelanggaran tidak dalam lingkup profesi sebagai advokat, sehingga hak imunitas yang hanya melekat pada profesi advokat menjadi gugur. Selain aspek pidana yang mengikat advokat jika melakukan pelanggaran, adapula aspek kode etik yang harus di junjung tinggi. ${ }^{21}$

18 Amiruddin, "Pertanggungjawaban Sosio Yuridis Advokat Terhadap Klien Dalam Menangani Perkara Tindak Pidana Korupsi Berdasarkan Undang-Undang Nomor 18 Tahun 2003 Tentang Advokat." Legal Opinion: Jurnal Ilmu Hukum 5, no. 5.

${ }^{19}$ Ida Wayan Dharma Punia Atmaja, loc.cit, h. 9

${ }^{20}$ Asshiddiqie, Jimly. "Upaya Perancangan Undang-Undang Tentang Larangan Merendahkan Martabat Pengadilan." Jurnal Hukum dan Peradilan 4, no. 2 (2015): 199222.

21 Mamengko, Rudolf S. "Product Liability Dan Profesional Liability Di Indonesia." Jurnal Ilmu Hukum 3, No. 9: 1-10. 
Suatu kekuasaan negara hukum yang diselenggarakan pemerintah yang didasarkan pada prinsip demokratis dibawah rule of law yang bermakna adanya pengakuan dan perlidungan hak asasi, kedaulatan hukum (rule of law) penolakan terhadap segala bentuk kesewenangwenangan kekuasaan, serta persamaan dihadapan hukum dan kemerdekaan kekuasaan kehakiman. Adalah merupakan ciri dan identitas dari negara Indonesia, dengan demikian semua unsur penegak hukum harus dapat memberi dukungan kesetaraan fungsi dalam menyelenggarakan tugas penegakan hukum. Bila ada kekuasaan lembaga peradilan yang independen, maka diyakini lembaga peradilan menjadi mekanisme yang kuat untuk mempertahankan konstitusi dan keadilan. Uraian tersebut menunjukkan korelasi antara fungsi lembaga peradilan dan proses demokratisasi, di dalam peradilan yang bebas penegak hukum akan berhadapan dengan sistem yang disebut penegakan hukum dalam melaksanakan tugas profesi. Didalam konteks ini agar profesi advokat mampu berperan maksimal melakukan penegakan hukum maka diperlukan suatu Organisasi Profesi Advokat yang kuat, mandiri dan Independen dalam sistem penegakan hukum di Indonesia. ${ }^{22}$

Penerapan Hak Imunitas dalam membela kepentingan klien harus ditafsir sebagai menjalankan tugas profesi yang dikaitkan dengan iktikad baik untuk mengukur benar atau salahnya perbuatan Advokat, misalnya apakah telah dilakukan perbuatan suap menyuap kepada unsur penegak hukum yang lain, atau merekayasa semua alat bukti, memalsukan alat bukti, atau upaya persekongkolan yang bermaksud untuk merekayasa suatu keputusan atau menyuruh untuk membuat suatu keterangan. Advokat tidak dapat langsung diidentifikasi secara subjektif sebagai telah melakukan perbuatan pelanggaran pidana sama dengan perbuatan klien nya kecuali ia menjadi bagian dari suatu kejahatan misal Advokat tertangkap tangan melakukan penyuapan. Dikaitkan dengan tatacara pemeriksaan Advokat yang dipanggil oleh pihak Kepolisian karena suatu tuduhan perbuatan pidana walaupun pihak pemeriksa berkewajiban untuk meminta keterangan dari PERADI untuk mengklarifikasi dan meminta tanggapan agar Advokat yang telah didakwa melanggar perbuatan pidana, apakah telah melanggar kode etik Advokat Indonesia pada suatu proses pemeriksaan Dewan Kehormatan PERADI, tentang apa yang diadukan kepada Dewan Kehormatan, namun jika tidak ditemukan bukti tentang kesalahan terhadap pekerjaan advokat selama melaksanakan tugas mendampingi Klien, maka

22 Prakata PERADI rancangan perubahan undangundang advokat no. 18 tahun 2003, disampakan kepada DPR RI sebagai sumbngan pikiran rancangan perubahan undangundang advokat no.18 tahun 2003, Jakarta tahun 2013. 
persidangan Dewan Kehormatan harus menyatakan dalam Putusannya Bahwa Advokat tersebut telah melakukan tugas dengan iktikat baik.

\section{KESIMPULAN}

Batasan dari Obstruction Of Justice, menyatakan 3 (tiga) unsur penting yaitu Tindakan tersebut menyebabkan tertundanya proses hukum (pending judicial proceedings);Pelaku mengetahui tindakannya atau menyadari perbuatannya (knowledge of pending proceedings); Pelaku melakukan atau mencoba tindakan menyimpang dengan tujuan untuk mengganggu atau mengintervensi proses atau administrasi hukum (acting corruptly with intent), Selanjutnya obstruction of justice merupakan delik materikl, sehingga delik tersebut mengindahkan adanya akibat yang ditimbulkan dari perbuatan, yakni perbuatan tercegah, terintangi atau tergagalkannya suatu penyidikan, penuntutan dan pemeriksaan sidang yang sedang dilaksanakan mengakibatkan lambatnya proses Peradilan sehingga tidak sesuai dengan prinsip peradilan yang sederhana, cepat dan biaya ringan.

Selain dari hak imunitas advokat sebagai bentuk perlindungan hukum seharusnya delik obstruction of justice disematkan pada delik pidana materil bukan delik formil sehingga penekanan kasus tersebut adalah akibat dari perbuatan itu, seyogyanya untuk menilai perbuatan Officium Nobille maka peninjauannya pada akibat agar interpretasi dari kata mencegah,merintangi,dan menghalangi tidak sebatas perbuatan semata melainkan ada akibat yang ditimbulkan.

\section{DAFTAR PUSTAKA}

\section{Buku}

Agustina, Shinta et.al, 2005, Obstruction Of Justice, Jakarta : Themis Book. Ahyar, Adardam, Tulisan dalam diskusi di Bandung, pada rakor IKADIN se-Jawa Barat dengan DPP IKADIN tanggal 21 Mei 2014.

Lamintang dan Theo Lamintang, 2009, Delik-Delik Khusus Kejahatan Membahayakan Kepercayan Umum tethadap Surat Alat Pembayaran Alat Bukti dan Peradilan, Jakarta: Sinar Grafika.

Risalah Undang-Undang Nomor 3 Tahun 1971, Rapat pleno terbuka ke 6, Pembicaraan Tingkat III (Pemandangan Umum Para Anggota) mengenai RUU Tentang Pemberantasan Tindak Pidana Korupsi P.2/1970-1971, Hari Jumat, 4 September 1970.

Winata, Frans Hendra Winata, 1995, Advokat Indonesia citra, idealisme dan keprihatinan, Jakarta : Pustaka Sinar Harapan 


\section{Jurnal}

Amiruddin,"Pertanggungjawaban Sosio Yuridis Advokat Terhadap Klien Dalam Menangani Perkara Tindak Pidana Korupsi Berdasarkan Undang-Undang Nomor 18 Tahun 2003 Tentang Advokat." Legal Opinion: Jurnal Ilmu Hukum 5(5).

Asshiddiqie, Jimly, 2015, "Upaya Perancangan Undang-Undang Tentang Larangan Merendahkan Martabat Pengadilan." Jurnal Hukum dan Peradilan, 4(2), 199-222.

Atmaja, Ida Wayan Dharma Punia, dan I. Wayan Suardana. "Hak Imunitas Advokat Dalam Persidangan Tindak Pidana Korupsi."Kertha Wicara: Journal Ilmu Hukum, 9 (4).

Eddy Os Hiariej, Guru Besar Hukum Pidana Fakultas Hukum UGM, Obstruction Of Justice dan Hak Angket DPR, lihat pula pada, https://www.pressreader.com/indonesia/kompas/20170721/2816124 20458169, pada hari 22 Maret 2021 pukul 19.22 WITA

Kresnadinata, Putu, and I. Putu Rasmadi Arsha Putra, 2019, "Batasan Perlindungan Advokat Saat Memberi Jasa Hukum Di Luar Pengadilan Ditinjau Dari Putusan Mk No. 26/PuuXi/2013." Kertha Wicara: Journal Ilmu Hukum ,8 (5),1-14.

Mamengko, Rudolf S. "Product Liability Dan Profesional Liability Di Indonesia." Jurnal Ilmu Hukum, 3(9), 1-10.

Yoga, I. Nyoman Darma, et.al, 2013, "Kewenangan Komisi Pemberantasan Korupsi Menangani Obstruction Of Justice Dalam Perkara Korupsi." Kertha Wicara: Journal Ilmu Hukum, 1(1), 1-14.

\section{Undang-Undang}

Kitab Undang-Undang Hukum Pidana

Kitab Undang-Undang Hukum Acara Pidana

Undang-Undang Nomor 20 Tahun 2001 Tentang Pemberantasan Tindak Pidana Korupsi

Undang-Undang Nomor 18 Tahun 2003 Tentang Advokat

Undang-Undang Nomor 48 Tahun 2009 Tentang Kekuasaan Kehakiman

Undang-Undang Nomor 19 Tahun 2016 Tentang Perubahan Atas UndangUndang Nomor 11 Tahun 2008 Tentang Informasi Dan Transaksi Elektronik 